\title{
ПРОДУКТИВНОСТЬ СОРТОВ И ГИБРИДОВ КАРТОФЕЛЯ ПИТОМНИКА ЭКОЛОГИЧЕСКОГО ИСПЫТАНИЯ
}

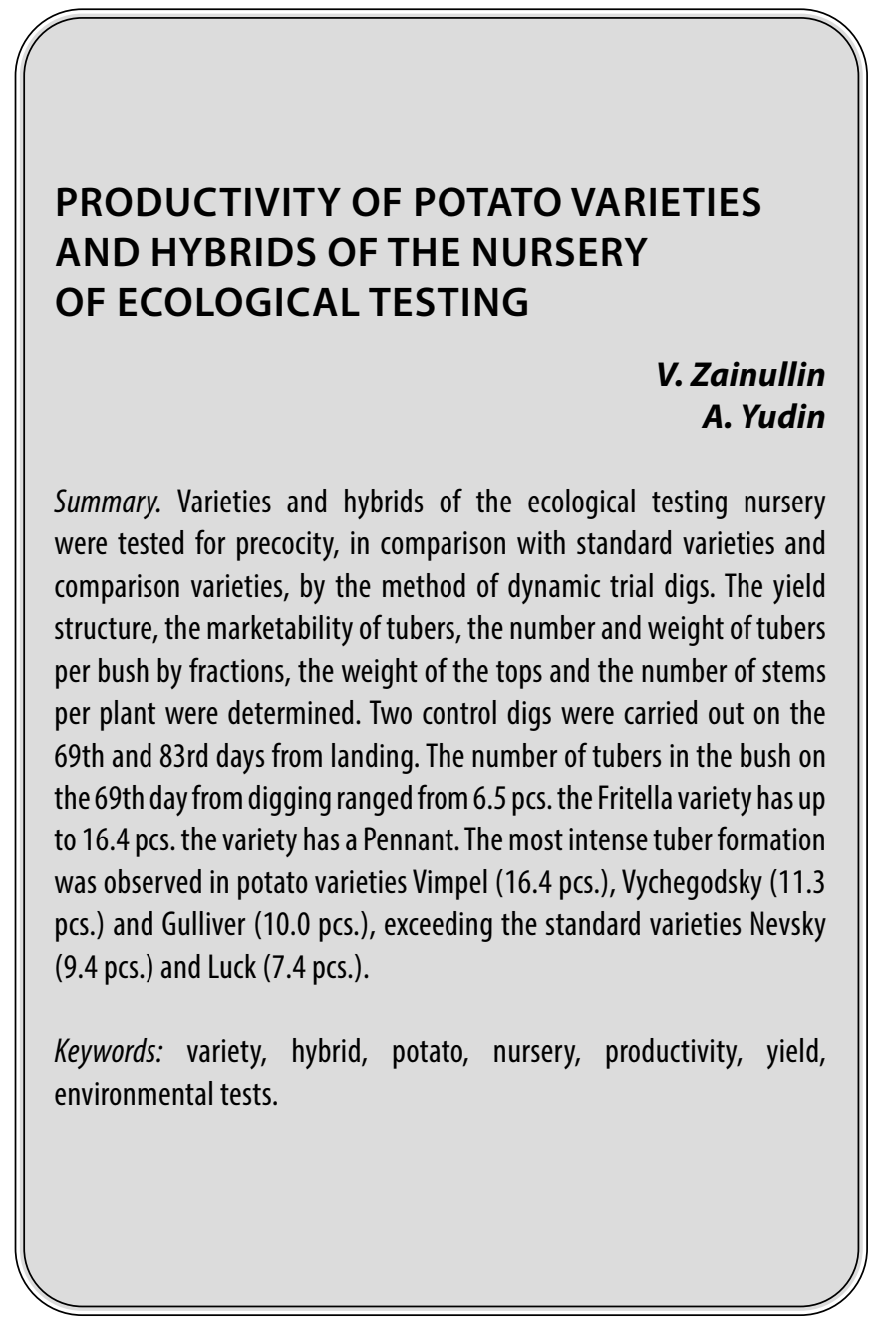

C орта и гибриды питомника экологического испытания проходили испытания на скороспелость, в сравнении со стандартными сортами и сортами сравнения, методом динамических пробных копок [1]. Определяли структуру урожайности, товарность клубней, количество и массу клубней на куст по фракциям, массу ботвы и количество стеблей на растении [2-3].

Были проведены две контрольные копки на 69-й и 83-й день от посадки. Количество клубней в кусте на 69-й день от копки колебалось от 6,5 шт. у сорта Фрителла до 16,4 шт. у сорта Вымпел. Наиболее интенсивное клубнеобразование наблюдалось у сортов картофеля Вымпел (16,4 шт.), Вычегодский $(11,3$ шт.) и Гулливер (10,0 шт.), превысив стандартные сорта Невский (9,4 шт.) и Удача (7,4 шт.) [4-5].
Зайнуллин Владимир Габдуллович

Д.б.н., nрофессор, в.н.С., Институт агробиотехнологий им. А.В. Журавского обособленное подразделение ФГБУН ФИЦ Коми НЦ УрО

$P A H$

zainullin.v.g@yandex.ru Юдин Андрей Алексеевич

К.э.н., н.С., Институт агробиотехнологий им. А.В. Журавского - обособленное подразделение ФГБУН ФИЦ Коми НЦ УрО РАН audin@rambler.ru

Аннотация. Сорта и гибриды питомника экологического испытания проходили испытания на скороспелость, в сравнении со стандартными сортами и сортами сравнения, методом динамических пробных копок. Определяли структуру урожайности, товарность клубней, количество и массу клубней на куст по фракциям, массу ботвы и количество стеблей на растении. Были проведены две контрольные копки на 69-й и 83-й день от посадки. Количество клубней в кусте на 69-й день от копки колебалось от 6,5 шт. у сорта Фрителла до 16,4 шт. у сорта Вымпел. Наиболее интенсивное клубнеобразование наблюдалось у сортов картофеля Вымпел (16,4 шт.), Вычегодский (11,3 шт.) и Гулливер (10,0 шт.), превысив стандартные сорта Невский $(9,4$ шт.) и Удача (7,4 шт.).

Ключевые слова: сорт, гибрид, картофель, питомник, продуктивность, урожайность, экологические испытания.

У сорта Вымпел отмечено самое большое количество нетоварных клубней весом меньше 30 г.- 10,8 шт., а у сорта Фрителла самое маленькое количество нетоварных клубней весом меньше 30 г.- 1,7 шт. Больше двух клубней в кусте весом больше 80 г наблюдали у сортов Армада, Варяг, Гулливер, Крепыш, Фрителла, Зырянец, Невский, гибрид 1657-7; у двух: сорта Кумач и гибрида 1603-7 не было обнаружено клубней весом более 80 г. Высокую урожайность на 69-й день от посадки показали сорта Гулливер (22,5 т/га) и Вымпел (22,1 т/га), низкая урожайность отмечена у гибрида 1603-7 (6,9 т/га), сортов Кумач (8,6 т/га) и Тайфун (8,6 т/га). Высокая товарная урожайность на 69-й день от посадки наблюдалась у сортов картофеля Армада (20,4 т/га) и Гулливер (20,1 т/га) что связано с большим количеством товарных клубней в кусте, самая низкая - у гибрида 1603-7 (4,2 т/га). Высокая 
Таблица 1. Структура общей урожайности сортов и гибридов картофеля (средние значения).

\begin{tabular}{|c|c|c|c|c|c|c|c|}
\hline \multirow{2}{*}{$\begin{array}{l}\text { № } \\
\Pi / \Pi\end{array}$} & \multirow[t]{2}{*}{ Сорт } & \multicolumn{3}{|c|}{$\begin{array}{l}\text { Фракционный состав клубней } \\
\text { одного куста }\end{array}$} & \multirow{2}{*}{$\begin{array}{l}\text { Среднее кол- } \\
\text { во клубней } \\
\text { в кусте, шт. } \\
\end{array}$} & \multirow{2}{*}{$\begin{array}{l}\text { Урожай-ность, } \\
\text { т/га }\end{array}$} & \multirow{2}{*}{$\begin{array}{l}\text { Товарная } \\
\text { урожайность, } \\
\text { т/га }\end{array}$} \\
\hline & & $<30$ гр. & 30-80 гр. & $>80$ гр. & & & \\
\hline 1 & Армада & 2,3 & 3,9 & 3,0 & 9,1 & 29,58 & 28,00 \\
\hline 2 & Варяг & 1,1 & 2,3 & 2,4 & 5,8 & 21,35 & 20,40 \\
\hline 3 & Вымпел & 5,0 & 8,0 & 0,9 & 13,9 & 30,92 & 26,02 \\
\hline 4 & Гулливер & 2,3 & 2,1 & 3,3 & 8,4 & 29,95 & 27,70 \\
\hline 5 & Краса Мещеры & 2,2 & 4,6 & 1,4 & 8,2 & 24,17 & 22,08 \\
\hline 6 & Крепыш, сс & 2,6 & 2,3 & 2,0 & 6,8 & 24,45 & 22,27 \\
\hline 7 & Кумач & 3,8 & 3,2 & 1,9 & 8,9 & 22,85 & 20,25 \\
\hline 8 & Метеор & 1,9 & 1,8 & 2,4 & 6,2 & 21,72 & 20,17 \\
\hline 9 & Тайфун & 1,3 & 1,5 & 1,7 & 4,5 & 14,82 & 13,80 \\
\hline 10 & Фрителла & 1,4 & 2,7 & 3,7 & 7,7 & 31,90 & 31,05 \\
\hline 11 & Зырянец, сс & 3,3 & 4,2 & 1,8 & 9,3 & 26,42 & 23,00 \\
\hline 12 & Вычегодский, сс & 6,8 & 5,3 & 0,8 & 12,9 & 23,40 & 17,70 \\
\hline 13 & $1603-7$ & 2,1 & 2,8 & 1,3 & 6,2 & 15,57 & 13,88 \\
\hline 14 & $1657-7$ & 2,6 & 2,8 & 3,3 & 8,8 & 33,40 & 31,55 \\
\hline 15 & Невский, st. & 3,4 & 4,7 & 1,4 & 9,5 & 21,80 & 18,90 \\
\hline \multirow[t]{2}{*}{16} & Удача, st. & 2,2 & 4,0 & 1,3 & 7,5 & 19,58 & 17,80 \\
\hline & $\mathrm{HCP}_{05}$ & 1,50 & 1,68 & 1,03 & 2,30 & 5,94 & 6,35 \\
\hline
\end{tabular}

Таблица 2. Урожайность и товарность исследуемых сортов и гибридов картофеля на 69-й и 83-й дни

\begin{tabular}{|c|c|c|c|c|c|c|}
\hline \multirow[b]{2}{*}{$\begin{array}{l}\text { № } \\
\text { ח/ }\end{array}$} & \multirow[b]{2}{*}{$\begin{array}{l}\text { Гибрид, } \\
\text { сорт }\end{array}$} & \multicolumn{2}{|c|}{ Урожайность клубней, т/га } & \multirow{2}{*}{$\begin{array}{l}\text { Прирост } \\
\text { в сутки } \\
\text { с 69-го по 83-й } \\
\text { день }\end{array}$} & \multicolumn{2}{|l|}{ Товарность, $\%$} \\
\hline & & $\begin{array}{l}\text { ранняя: } \\
\text { на 69-й день } \\
\text { от посадки } \\
\end{array}$ & $\begin{array}{l}\text { общая: на 83-й } \\
\text { день } \\
\text { от посадки }\end{array}$ & & $\begin{array}{l}\text { на 69-й день } \\
\text { от посадки }\end{array}$ & $\begin{array}{l}\text { на 83-й день } \\
\text { от посадки }\end{array}$ \\
\hline \multicolumn{7}{|c|}{ ранние } \\
\hline 1 & Армада & $23,1 \pm 3,5$ & $29,6 \pm 3,2$ & 0,50 & 88 & 95 \\
\hline 2 & Крепыш, сс & $18,7 \pm 1,6$ & $24,5 \pm 2,4$ & 0,45 & 90 & 91 \\
\hline 3 & Метеор & $18,2 \pm 2,8$ & $21,7 \pm 1,1$ & 0,27 & 84 & 93 \\
\hline 4 & Удача, st & $15,1 \pm 1,6$ & $19,6 \pm 2,0$ & 0,35 & 90 & 91 \\
\hline \multicolumn{7}{|c|}{ раннеспелые } \\
\hline 5 & Гулливер & $22,5 \pm 3,7$ & $30,0 \pm 2,7$ & 0,58 & 89 & 92 \\
\hline 6 & Тайфун & $8,9 \pm 1,0$ & $14,8 \pm 0,4$ & 0,45 & 76 & 93 \\
\hline \multicolumn{7}{|c|}{ среднеранние } \\
\hline 7 & Краса Мещеры & $18,1 \pm 2,4$ & $24,2 \pm 1,4$ & 0,47 & 76 & 91 \\
\hline 8 & $1657-7$ & $19,4 \pm 3,9$ & $33,4 \pm 3,6$ & 1,08 & 89 & 94 \\
\hline 9 & Зырянец, сс & $19,3 \pm 3,1$ & $26,4 \pm 1,9$ & 0,55 & 80 & 87 \\
\hline 10 & Невский, st & $16,6 \pm 3,2$ & $21,8 \pm 2,4$ & 0,40 & 86 & 87 \\
\hline \multicolumn{7}{|c|}{ среднеспелые } \\
\hline 11 & Варяг & $15,7 \pm 3,2$ & $21,4 \pm 0,6$ & 0,44 & 90 & 96 \\
\hline 12 & Вымпел & $22,1 \pm 1,8$ & $30,9 \pm 1,1$ & 0,68 & 59 & 84 \\
\hline 13 & Кумач & $8,6 \pm 2,1$ & $22,9 \pm 2,7$ & 1,10 & 58 & 89 \\
\hline 14 & Фрителла & $16,4 \pm 0,7$ & $31,9 \pm 3,1$ & 1,19 & 93 & 97 \\
\hline 12 & Вычегодский, сс & $12,6 \pm 1,7$ & $23,4 \pm 2,0$ & 0,83 & 47 & 76 \\
\hline \multicolumn{7}{|c|}{ среднепоздний } \\
\hline 13 & $1603-7$ & $6,9 \pm 1,5$ & $15,6 \pm 1,5$ & 0,67 & 61 & 89 \\
\hline \multicolumn{2}{|c|}{$\mathrm{HCP}_{05}$} & 6,9 & 5,9 & & & \\
\hline
\end{tabular}




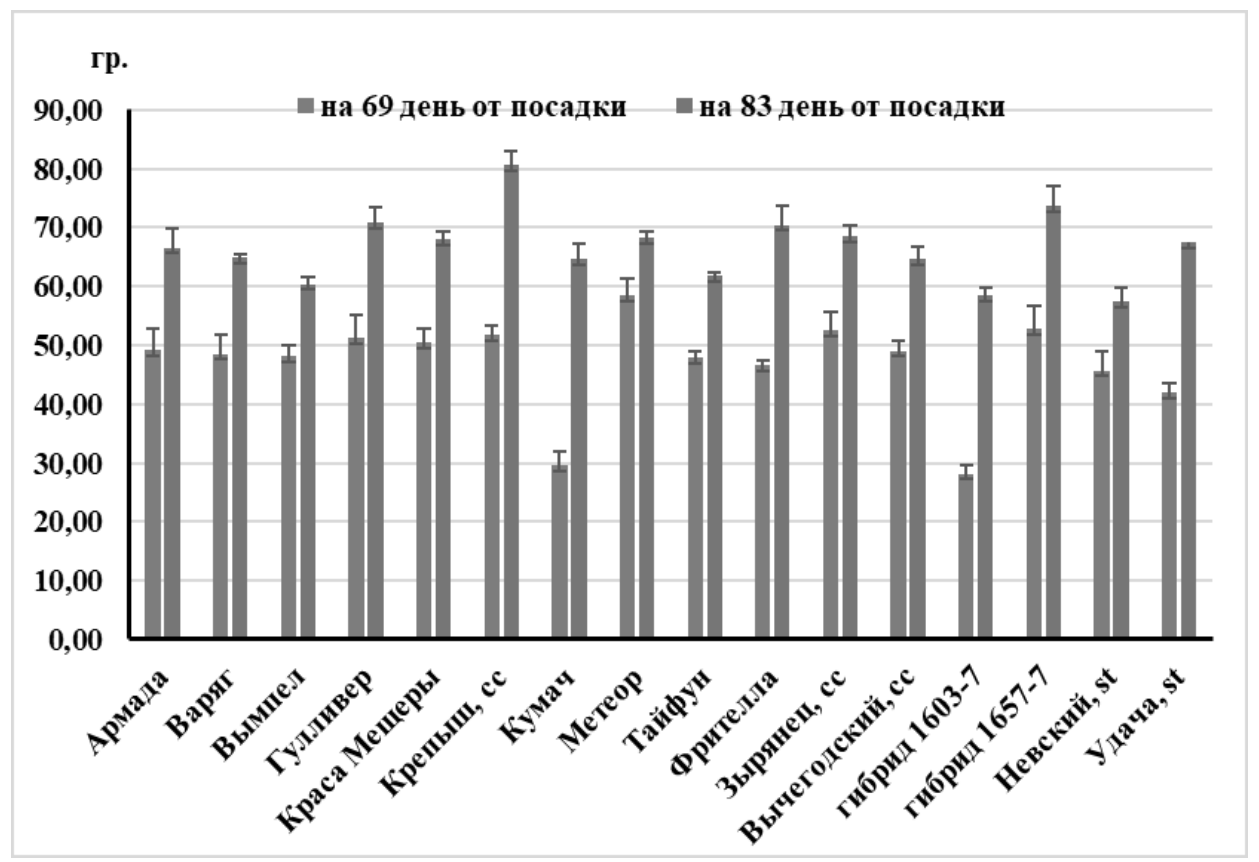

Рис. 1. Изменение средней массы клубня за 14 дней

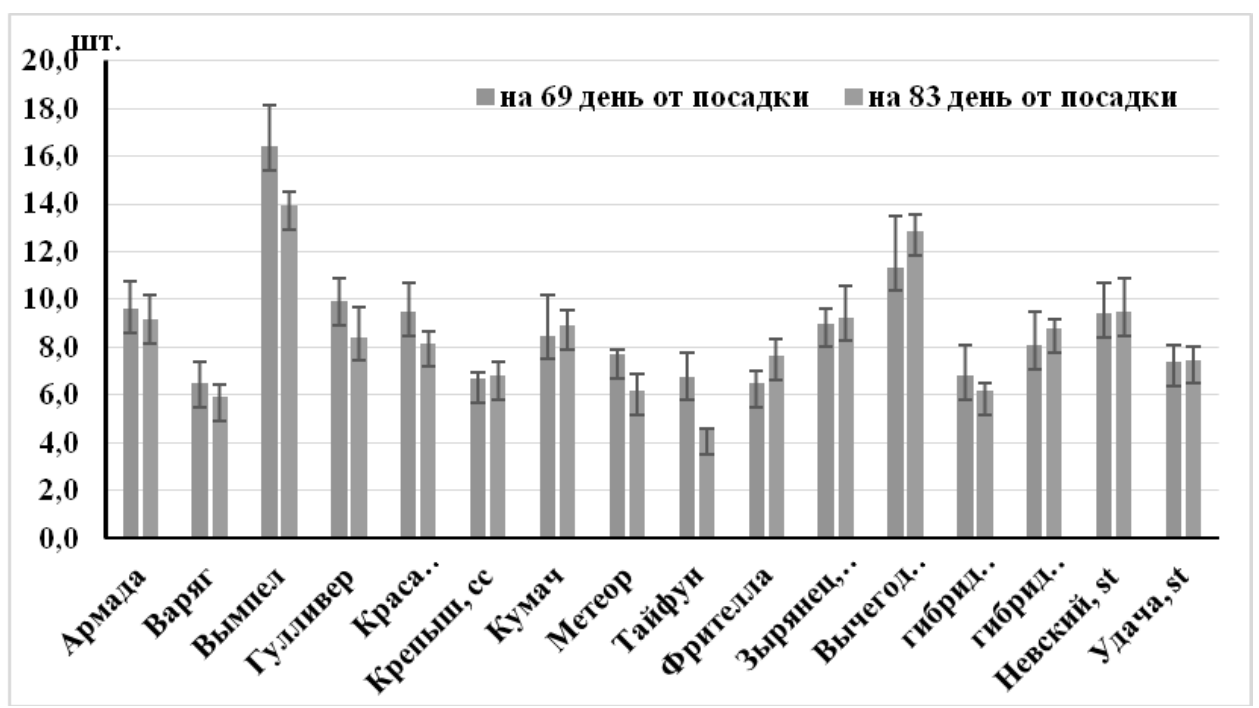

Рис. 2. Изменение среднего количества клубней с куста за 14 дней

продуктивность надземной биомассы отмечена у сортов картофеля Крепыш (15,3 т/га), Фрителла (12,3 т/га) и Зырянец $(12,1$ т/га), низкая продуктивностью отличились сорт Метеор (6,9 т/га) и стандартный сорт Удача (6,6 т/га).

Структура общей урожайности (на 83-й день от посадки) дана в таблице 1.

К моменту сбора урожая на 83-й день от посадки отмечено, что наибольшее количество клубней в кусте дали сорта: Вымпел (13,9 шт.) и Вычегодский (12,9 шт.), превысив стандарты на 4,4-3,4 шт. (Невский); 6,4-5,4 шт. (Удача), сорт сравнения Крепыш дал 6,8 шт. клубней. Наименьшее количество клубней в кусте наблюдалось у сорта Тайфун - 4,5 шт. Наибольшее количество крупных клубней массой больше 80 гр. было у сортов Армада, Гулливер, Фрителла, гибрида 1657-7, которое превысило число клубней стандартных сортов более чем в 2 раза. Несмотря на то, что сорт Вымпел имел наименьшее количество клубней массой > 80 гр., у него 
отмечено наибольшее количество клубней среднего размера массой от 30 до 80 гр.

Высокая урожайность отмечалась у гибрида 1657-7 (33,4 т/га), сортов Фрителла (31,9 т/га), Вымпел (30,92 т/ га), Гулливер (29,95 т/га) и Армада (29,58 т/га).

Для этих сортов и гибрида отмечена высокая товарная урожайность: гибрид 1657-7 (31,6 т/га), сортов Фрителла (31,1 т/га), Вымпел (26,0 т/га), Гулливер $(27,7$ т/га) и Армада (28,0 т/га). Также общую урожайность выше стандартных сортов Невский $(21,8$ т/га) и Удача $(19,6$ т/ га) показали сорта картофеля Краса Мещёры (24,2 т/га), Крепыш (24,45 т/га), Кумач (22,9 т/га), Зырянец (26,4 т/ га), Вычегодский (23,4 т/га).

Провели анализ динамики урожайности клубней, определили прирост в сутки с момента учета массы и количества клубней на 69-е и 83-е сутки со дня посадки и рассчитали товарность урожая (таблица 2).

Были выделены сорта и гибриды, которые практически не изменили значение товарности за 14 суток: ранние сорта Крепыш, Удача, Метеор; среднеранний сорт Невский; изменилось незначительно (в пределах 5-9\%): ранний сорт Армада, раннеспелый сорт Гулливер, среднеранний сорт Зырянец, гибрид 1657-7; среднеспелые сорта Варяг, Фрителла. Наибольшее измене- ние товарности клубней за 14 суток показали сорта: раннеспелый - Тайфун (на 17\%), среднеранний - Краса Мещеры (на 15\%); среднеспелый - Вымпел (на 25\%); Кумач (на 31\%); Вычегодский (на 29\%); среднепоздний гибрид 1603-7 (на 28\%). У сортов Фрителла, Кумач и гибрида 1657-7 установлен самый высокий прирост массы клубней в сутки в промежуток между определением ранней и общей урожайности - 1,19; 1,10; 1 ,08 соответственно.

Таким образом, можно сказать, что условиях теплого сухого вегетативного периода 2020 года в среднетаежной зоне Республики Коми ранний сорт Армада показал себя как раннеспелый; раннеспелый сорт Тайфун, среднеранний сорт Краса Мещеры как среднеспелые; среднеранний сорт Невский как ранний; среднеспелые сорта Варяг, Фрителла как среднеранние; среднепоздний гибрид 1603-7 как среднеспелый [6-7].

Было установлено, что прирост урожая за 14 суток происходил за счет увеличения массы клубней (рисунок 1).

Достоверных различий в увеличении числа клубней в период с 69 до 83 суток не выявлено (рисунок 2).

При учете общей урожайности выявили уменьшение количества клубней у сортов Вымпел и Тайфун.

\section{ЛИТЕРАТУРА}

1. Тулинов, А.Г. Изучение нового сорта картофеля Вычегодский по комплексу хозяйственно ценных признаков / А.Г. Тулинов, А.Ю. Лобанов // Аграрная наука Евро-Северо-Востока.— 2020. — № 21(3).—C. 283-292. D01: https://doi.org/10.30766/2072-9081.2020.21.3.283-292.

2. Исследование сортов и гибридов картофеля из селекционного питомника ФИЦ Коми НЦ УрО РАН на наличие маркеров устойчивости к фитопатогенам / В.Г. Зайнуллин, А.А. Юдин, А.А. Кущ, А.И. Некрасова, О.П. Малюченко, С.А. Быков // Вестник Курской государственной сельскохозяйственной академии.—2019.—№ 7.—С. 85-91.

3. Методика исследований по культуре картофеля НИиКХ.— М.: Агропромиздат.— 1967.— 114 с.

4. Симаков, Е.А. Методические указания по технологии селекционного процесса картофеля / Е.А. Симаков, Н.П. Склярова, И.М. Яшина.— М.: 000 «Редакция журнала «Достижения науки и техники АПК», 2006. — 70 с.

5. Защита картофеля от болезней, вредителей и сорняков / Б.В. Анисимов, Г.Л. Белов, Ю.А. Варицев, С.Н. Еланский, Г.К. Журомский, С.К. Завриев, В.Н. Зейрук, В.Г. Иванюк, М.А. Кузнецова, М.П. Пляхневич, К.А. Пшеченков, Е.А. Симаков, Н.П. Склярова, З. Сташевски, А.И. Усков, И.М. Яшина.— М.: Картофелевод, 2009. - 272 c.

6. Доспехов, Б.А. Методика полевого опыта (с основами статистической обработки результатов исследований)/ Б.А. Доспехов. - М.: Агропромиздат, 1985.- $351 \mathrm{c}$.

7. Система земледелия Республики Коми: монография/ Г.Т. Шморгунов, А.Г. Тулинов, Н.В. Булатова, С.В. Коковкина, З.К. Цветкова, А.В. Облизов, А.А. Юдин, Н.Т. Чеботарев, Р.А. Беляева, А.Ф. Триандафилов, Э.А. Блох, П.А. Макаровский, Ю.М. Шехонин, А.А. Хомченко, Н.В. Колегов, В.И. Ермолина, Т.В. Косолапова, Е.Ф. Каракчиева, Н.И. Пелевина, Н.С. Шестопалова, А.В. Бабела, С.И. Семенчин, Г.Г Романов., Т.В. Ортякова, А.Ю. Лобанов, Н.В. Регорчук, О.Н. Шершунова, Д.А. Попов — Сыктывкар: ГОУ ВО КРАГСиУ, 2017. — 225 с.

( ) Зайнуллин Владимир Габдуллович ( zainullin.v.g@yandex.ru ), Юдин Андрей Алексеевич ( audin@rambler.ru ). Журнал «Современная наука: актуальные проблемы теории и практики» 